\title{
Development of Ergonomic Penjas Ball
}

\author{
Eka Nugraha*, Ricky Wibowo, Burhan Hambali \\ Physical Education Departement, Faculty of Sport and Health Education \\ Universitas Pendidikan Indonesia \\ Bandung, Indonesia \\ *ekafok@upi.edu
}

\begin{abstract}
Media/learning tools are one of the important factors to help students succeed in increasing the effectiveness and efficiency of achieving learning objectives in the teaching and learning process in schools. The ball is the dominant tool $/$ media in sport learning. The results of the preliminary study show that there are still many PJOK teachers who have not maximized the learning process, among others, because physical education is still sport oriented and still uses formal sports tools, and the limited availability of sport learning tools/media is also not available on the market. The purpose of this study is to design an ergonomic tool/instructional media/learning model in accordance with the results of anthropometric mapping of Indonesian students. The research method used is a mixed method using basic research design (Design Basic Research $=$ DBR). Instruments used to obtain data include study of documentation, surveys, interviews, and direct observation. The population is all Indonesian junior high school students with a sample of affordable 4th grade students. Based on the analysis of data from previous research results, almost $95 \%$ of PJOK teachers still use formal sports learning tools and media without considering the problems associated with anthropometric mapping of students with ergonomic tools/learning media. The conclusions of the research are the need for ergonomic sport media/balls that are in accordance with the anthropometric mapping of students, in line with the various literatures / theories and facts that must be faced in modern sport learning.
\end{abstract}

Keywords—media/learning tools; ergonomic; penjas ball

\section{INTRODUCTION}

Based on the background above, based on the results of the PJOK teacher interviews, almost $95 \%$ of PJOK teachers still use formal sports learning tools/media, classic reasons and the fact that formal sports learning tools/media for junior size are rare in the market, and people in general still consider activities of sport learning in schools is a sporting activity, strengthened by the official activities of the government, such as O2SN activities, championship for sports obscurity at the elementary, middle and high school levels.

Sport media/learning tools is one part that is inseparable from the success of learning outcomes, various modifications to the tool/basketball-volleyball, and other techniques one of which will enrich the possibility of successful execution of skills and various types of equipment and facilities in accordance with learning will enhance learning and teaching more interesting and effective in various learning processes of Penjas/PJOK [1-4]. However in reality there are still many schools including PJOK teachers still do not understand that the media/learning tools can influence the achievement of learning objectives, marked by the use of formal sports equipment/media in schools in West Java, only tend to find facilities with outstanding formal equipment in the market, without thinking about the suitability of the students, especially if viewed from the side of the appropriateness between the tools/media and their activities usually in the industrial world called ergonomics.

Ergonomics itself according to Stockbridge human related factors are body knowledge of their abilities, limitations, and human characteristics relevant to design [5]. Santosa G. argues: ... it is very important to think that all the equipment is adapted to the anatomical and physiological conditions of the child, for their safety and that the developing skills can be maximized. These are Ergonomic problems [6], Strengthened edits from Relly, Sports 'achievements' starting with young people and teenagers now ... for the application of pediatric ergonomics, it must be understood that children are not adults but they will grow, develop according to their own way, so it is very appropriate that our students need learning tools/media that are in accordance with the character, the exact nature of growth and development both physically and mentally, the right learning tools/media are needed $[7,8]$.

Ergonomics problems are a problem that should not be ignored in penjas learning, often our students avoid being actively involved in penjas learning activities, especially young women who are weak and lacking in confidence, always have reasons to avoid because Indonesian standard formal balls no. 08-0615-1989, not in accordance with the anthropometrics of class VII students.

Referring to this background, the expected goals of the results of this second phase of research, in detail the objectives of this study include:

Designing a model of penjas tools/learning media, in the form of manipulative tools (foam ball/penjas ball) for large ball games, which are in accordance with the requirements: function, mechanics, attractive appearance and security aspects. Make steps in the process of making an ergonomic penjas ball model (assisted by nano technology experts in the field of material physics FTI ITB).

Doing a test mechanical functions in the laboratory.

Conducting a testing of wear in selected junior high schools. (in the form of studies related to the use of penjas 
balls, as well as a means of feedback for the perfection of the penjas learning manipulative tool.

Learning or practicing is a process characterized by behavioral changes or changes in skills in settled individuals. Learning characteristics or indicators included that; 1) learning is the effect of practice or experience 2) the learning process cannot be observed directly, but what can be seen is the result in the form of increasing abilities or skills, and 3) changes in individual abilities are permanent [9]

Media is one component in the system that influences learning outcomes, Tinning explains that there are four main components in teaching planning namely aims, material (method), and evaluation (assessment \& evaluation) [10]

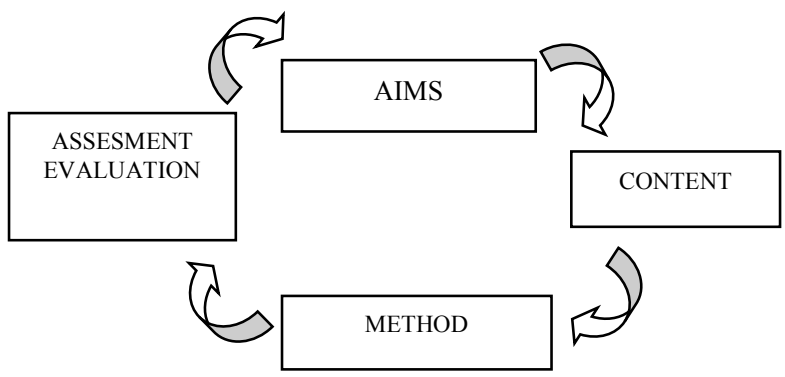

Fig. 1. Cycle in learning planning [10].

In accordance with the name and function of "aids", that the function of aids includes helping and facilitating students in mastering the goals and material set by the teacher. It is clear, that it must be planned and made before learning begins, and of course the learning media must be in accordance with the objectives and material to be taught. Abdulhak \& Djaenudin Harun explained that the principle of media selection must refer to; 1) the media must refer to the objectives to be achieved, 2) must be based on the theoretical basis, 3) adapted to the characteristics of students, 4) according to the learning style and abilities of students, and 5) in accordance with environmental conditions \& facilities available [11]. Strengthened by Gallahue "The selection, placement, and use of effective organizations of the lesson" [12].

According to Thomas, Lee \& Thomas, the relationship between penjas learning media and facilities (penjas) will improve the ability of student learning, making the learning environment safer, balancing learning issues and the center of attention. The tools are divided into 2 two parts by volume: small tools and large devices (Small Equipment \& Large Equipment), these small tools are generally categorized into 3 categories: tools for manipulatives (for example, balls), single use tools (such as, batting) tee) and supporting materials (such as, Connes, music player) [13]

The research that has been carried out related to the learning tool/media in the teaching and learning process, including the following:

The results of the research conducted by Irawati Hasanah and Eka Nugraha in 2015, obtained significant results of the use of modification tools on learning outcomes in SD Masekdas students.
The results of the Ongko Wijoyo and Eka Nugraha in 2015, study of the use of modified balls have provided a positive subjective impression compared to the use of formal balls in volleyball learning.

The results of research by Yuliana Sabrina and Eka Nugraha in 2015, have shown a significant increase in the use of modified ball on the active time of student learning.

Why the use of penjas learning tools/media has increased a variety of positive things, among others due to the learning of using tools/media in big ball games, has triggered students' enthusiasm to be better. It means that when the researcher gives a modified ball that matches the character and nature of the penjas learning at that time, students dissolve into a pleasant atmosphere, with friendly and interesting learning tools/media. The students were quite enthusiastic in following the study because there were no obstacles from the environment and tools, so learning went quite effectively. After being evaluated and the results analyzed, there are significant improvements compared to the use of formal sports tools/media

The function of the penjas tool/learning media on penjas learning as a vehicle for students to channel excess energy, channel their understanding (cognitive), and channel the ability to make decisions that are right and fast, which can also be manifested in the form of certain basic movements (psychomotor) when doing activities, not to mention reflecting personal responsibility and social responsibility when the game is ongoing.

Below will be shown a variety of manipulative tools, in the form of foam basketball/handball made from waste oil $(\mathrm{PU}=$ poly urethane) or based on natural rubber $(\mathrm{NBR}=$ Nylo Butan Ruber), or cellulose from leftover fruit waste or combined of all three.

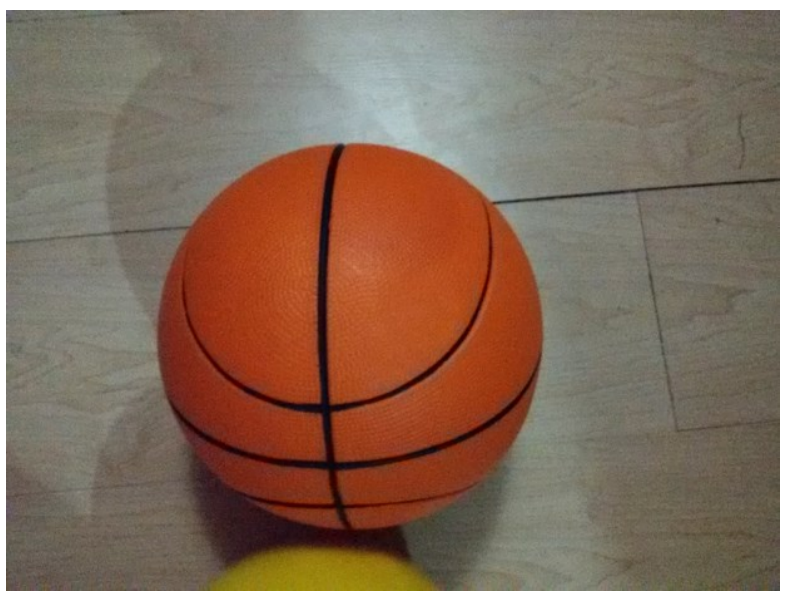

Fig. 2. Sport basketball from PU

Figure 2, the types of manipulative tools for learning penjas/penjas balls that are available are limited and are still not available in the general market, providing for limited circles as partners of the PSMP Directorate of Education and Culture. All of these balls are produced in foreign countries (China, the Netherlands, America and several other European 
countries), and are not necessarily in accordance with the anthropometric mapping of SMTP students in Indonesia.

From the previous explanation that the penjas tool/learning media, especially manipulative tools have a very central role in the learning process. Even this media/learning tool is able to convey messages directly in various realms of learning. This media is very effective in helping students achieve the expected learning goals. Through this research the author will conduct a theoretical review of the ergonomic tools/learning media and design a model of physical manipulative tools in accordance with anthropometric mapping for SMTP students in Indonesia.

\section{RESEARCH METHOD}

The method applied in this study is a mixed method with basic research design (Design Bases Research) [14], where various literatures agree that this design approaches a fairly long time consisting of various repetition designs, developments and revisions $[15,16]$, as for the design in figure 3 .

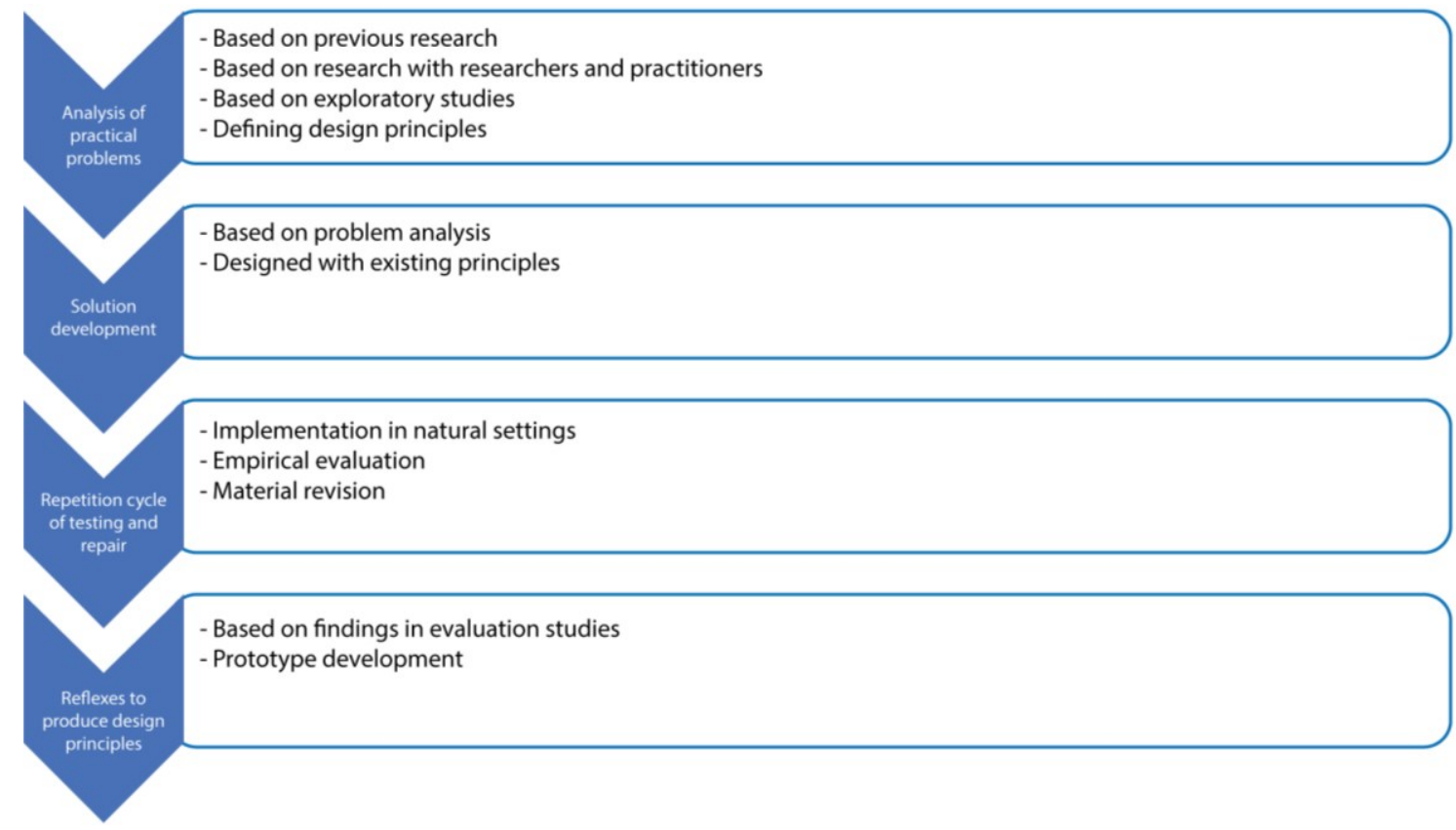

Fig. 3. Basic research design [15].

Steps for developing basic research design. Analysis of practical problems: based on the results of interviews with Penjas teachers in previous studies $95 \%$ of teachers in West Java still use the media/formal tools of sports in learning Physical Education (PJOK) for various reasons, also based on the results of anthropometric mapping surveys related to Penjas media/learning tool has no conformity, so that it produces recommendations. The use of media/formal sports tools in penjas learning is not appropriate if it is associated with ergonomic rules, media/equipment specifically for penjas learning needs to be designed in accordance with good, safe, comfortable and interesting, so that it will be in harmony with the physical and psychological growth of middle school students [17].

Development of solutions based on the results of previous research and based on existing literature and facts, many authors believe that homemade equipment or modifications will be designed according to what teachers feel to enrich better physical education programs, in accordance with Piaget's constructive learning theory [18]. Bucher and Crotec suggest that the design and manufacture of facilities/tools should be designed futuristically [19].
Repeat cycle Testing and repair. The implementation in the natural setting of the previous research results was strengthened by various literations, based on facts in the field and the results of discussion forums from FPOK and the nanotechnology laboratory of ITB Material Physics, old Chinese foam balls made from PU (poly urethane) made from oil residue. raw material has been damaged due to storage and its lifetime has expired, from this condition a new idea arises that the outer coating material made from cellulose material based on the residual fiber of commonly disposed plant material can be utilized. The next idea can be mixed with natural rubber (NBR) or PU itself. The new idea will be tested in the laboratory, together with designing the pattern of the No. 5 penjas basketball that has been adapted to the anthropometric mapping of class VII students.

Reflection to produce Design principles. Based on the results of previous studies of foam balls made in China, an ergonomic Penjas basketball/handball prototype design was developed. 


\section{RESULTS}

The results of the literature analysis and anthropometric mapping of class VII students in the 2016 study, the prototype of an ergonomic penjas ball was designed as in table 1 .

TABLE I. The Prototype of AN ERgonomic Penjas Ball

\begin{tabular}{|c|c|c|c|}
\hline Test type & Unit & Requirement & Note \\
\hline $\begin{array}{l}\text { Penjas ball } \\
\text { condition. } \\
\text { The condition of } \\
\text { the ball remains } \\
\text { round after the } \\
\text { reflection occurs. } \\
\text { The state of the } \\
\text { surface of the ball } \\
\text { follows the } \\
\text { contours of the } \\
\text { student's/learner's } \\
\text { hand }\end{array}$ & - & $\begin{array}{l}\text { The surface of } \\
\text { the grain is } \\
\text { rough, not } \\
\text { slippery/sticky } \\
\text { There is no } \\
\text { residual mold } \\
\text { that is dangerous. } \\
\text { The outer surface } \\
\text { is covered by } 2 \\
\text { layers of material } \\
\text { with high density } \\
\text { but not rigid. }\end{array}$ & $\begin{array}{l}\text { The surface of the } \\
\text { ball is not slippery } \\
\text { and returns to } \\
\text { recovery as long as it } \\
\text { is fast, friendly and } \\
\text { easily manipulated. }\end{array}$ \\
\hline $\begin{array}{l}\text { Circumfence of the } \\
\text { ball. } \\
\text { Penjas basketball } \\
\text { no.5 }\end{array}$ & $\mathrm{cm}$ & $\begin{array}{l}68.00-73.00 \\
\leq 1.5\end{array}$ & $\begin{array}{l}\text { The circumference of } \\
\text { the ball is adjusted by } \\
\text { mapping } \\
\text { Range of palms and } \\
\text { fingers open. Average } \\
\text { of } 14.07 \text {, mean head } \\
\text { circumference: } 49.04 \\
\text { and mean BMI }=2.0\end{array}$ \\
\hline $\begin{array}{l}\text { c. Basketball } \\
\text { weight no.5 }\end{array}$ & gram & Range 350-410 & $\begin{array}{l}\text { Look for the ideal } \\
\text { weight that is the } \\
\text { safest impact of } \\
\text { reflection for the head } \\
\text { circumference range, } \\
\text { average: } 49.04\end{array}$ \\
\hline Refle & $\mathrm{cm}$ & $\begin{array}{l}\text { Range of SNI } \\
120-140, \\
\text { Average range of } \\
\text { penjas ball } 80- \\
110\end{array}$ & $\begin{array}{l}\text { If the ball is dropped } \\
\text { at an altitude of } 180 \text {, } \\
\text { it will bounce } \\
\text { between } 80-110 \text {. } \\
\text { Average height: } \\
150.28 \text {, average leg } \\
\text { length } 75.42\end{array}$ \\
\hline $\begin{array}{l}\text { Seam width/boundar } \\
\text { line between panels }\end{array}$ & $\mathrm{cm}$ & $\leq 0.60$ & $\begin{array}{l}\text { Seam/boundary line } \\
\text { of dark colored balls. }\end{array}$ \\
\hline Stiffness/endurance & & $\begin{array}{ll}\leq 50 . & \\
\text { Appearance does } \\
\text { not } \quad \text { change } \\
\text { during normal } \\
\text { use }\end{array}$ & $\begin{array}{l}\text { The ball is kept clean } \\
\text { in a dry room, } \\
\text { humidity and } \\
\text { temperature as well as } \\
\text { a certain time }\end{array}$ \\
\hline
\end{tabular}

\section{DISCUSSION AND IMPLICATION}

Traditionally the development of prototype tools/learning media both theoretical development through literature, as well as direct field research always requires a long span of time and is carried out with experimental revisions, according to the basic research design concept should be a long time approach, which contains various design repetitions, development and revision [20-22]. Why are the media/learning tools of Penjas so important? because in Penjas ball learning becomes the main media and the only penjas learning tool that is directly related especially to the learning of game activities (invasion games, Fielding games, net games and Target games), in the international charter of physical education and sport, in article no 5 planning and the provision of facilities and equipment are very essential for Physical and Sports education [23].

Penjas equipment is directly related to the wearer, therefore designing a penjas ball must go through specific criteria both its function, an attractive appearance, its security, and is easy to manipulate and adapt to physiological, sociological and psychological developments.

\section{REFERENCES}

[1] M.A. Chase, A. Melisa., M.E. Ewing., C.D. Lirgg \& T.R. Georgre, The Effects of Equipment Modification on Children's Self-I and Basketball shooting Performance, Research Quarterlt for Exercise and Sport, pp. 159-168, 08 february 1994, publish on line 2013

[2] T.L.P. \&. H.A.H. Pellet, Influence of Ball Weigth on Junior High School Girls' Volley Performance', Vols. -, no. 78, 1994.

[3] P R. \&. G.E. Florina, Specific Skills Depelopment Using Appropriate Tools in the Tennis game, vol. XVII, no. 2, 2017.

[4] T. Gulhane., Need for Advanced Facilities and Equipmentin Physical Education Colleges., vol. 1, no. 6, 2014.

[5] A. Chapanis, Ergonomics in product development: a Personal View, vol. 38 , no. 8,1995 .

[6] S. Giriwijoyo, Ilmu faal Olahraga, Bandung: PT. Rosda Karya, 2015.

[7] T. Reilly, Ergonomics in Sport and Physical Activity: Enhancing Performance and improving safety., USA: www Human Kinetics.com, 2010

[8] R. Thomas, The advanted of Ergonomics., www,orosha.org, -, 2015.

[9] R. Schmidt., Motor Learning \& Performance, Illionis,USA: Human kinetics, 1991.

[10] R. Tinning, Becoming a Physical Education Teacher, Australia: Pearson Education, 2001.

[11] I.A. \&. D. Harun, Media Pembelajaran, in Media Pembelajaran, Bandung, UPI, 2003.

[12] D.L. Galahue, Developmental Physical Education for Today's Children., USA: Brown \& Benchmark, 1996.

[13] T.R. \&. L. Thomas, Ergonomics in Workplace, www,hse.ie, 2010.

[14] S.M.S.S. Jeanette Navakovich, Designing Curriculum to Shape Profesinal social Media Skills and Identiity in Visual Community of Practice, vol. 2016.11.002, 2016.

[15] T.R.T. Amiel, Design based research and educational technology:Rethinking technology and rsearch agenda., vol. 11, 2008.

[16] J.P.a.D. Laubscher, Design-based research: is this a suitable methodology for short-term projects?, vol. 53, no. 1, 2016.

[17] H.F.M. \&. D.B.E. Nugraha, Physical Education learning media based on Antropometric Mapping for SMP Student West Java-Indonesia Bandung, 2017.

[18] A. Mendez-Gimenez, Self-made material in Physical education Contexts: an Innovative complement to Instructional models, Crotia, 2014.

[19] L. Bucher A.C. \& Krotec, Mangemen of Physical Education and Sport, New York: Mac Graw Hill., 2002

[20] D. Walker, Toward Productive design studies, Routledge, London, 2006

[21] H. Buchardt, "From design research to large scale impact," education design research, Routledge. London, 2006.

[22] T. \&. S. Anderson, Design-based resarch: a Decade of Progress in Education Research?, vol. 41, no. 1, 2012.

[23] National Children hospital, New national study finds increas in Physical education class-related injuries, 2009. 